Prepared in cooperation with the City of Wichita, Kansas

\title{
Determination of Streamflow of the Arkansas River near Bentley in South-Central Kansas
}

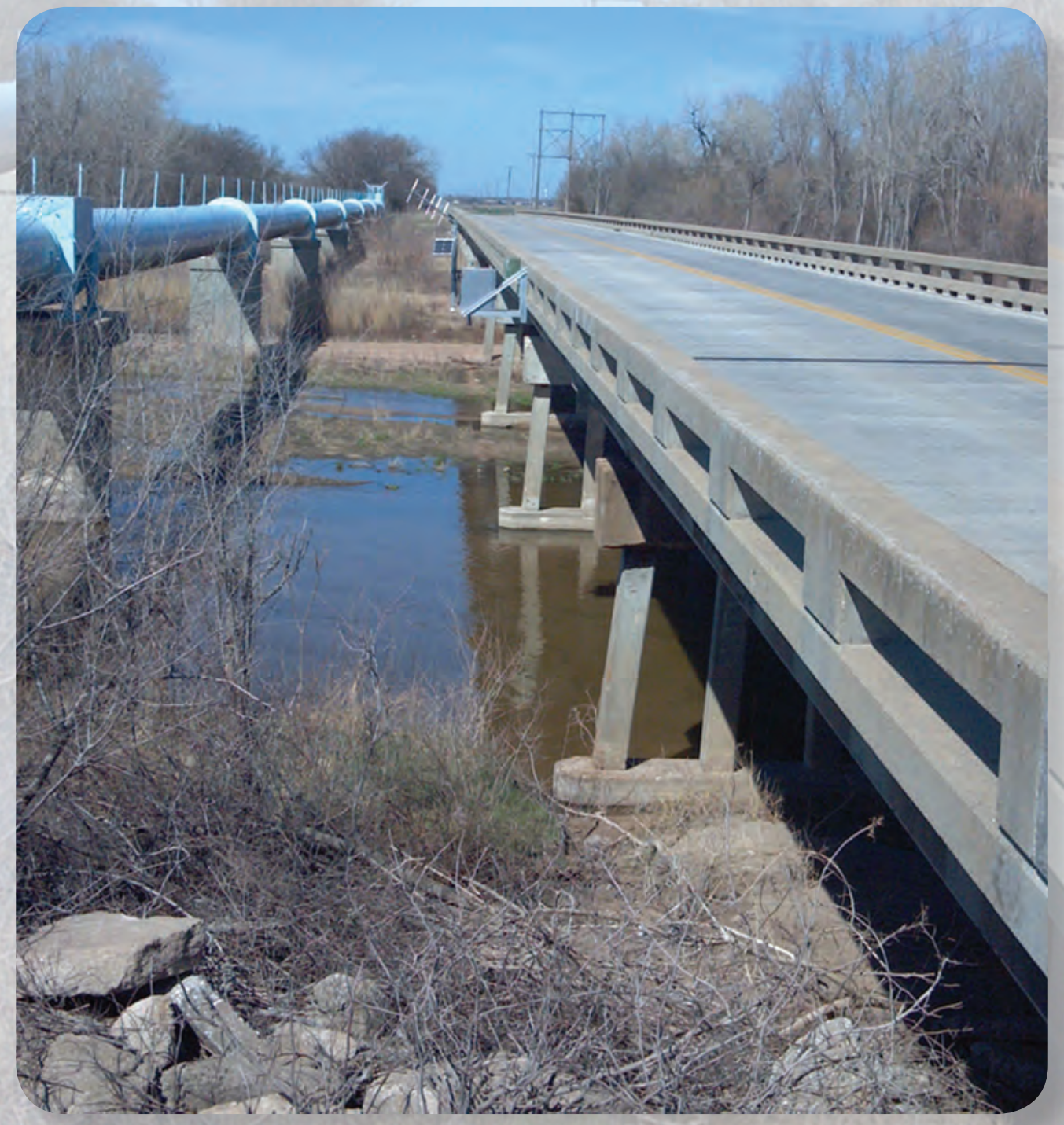

Scientific Investigations Report 2012-5059

U.S. Department of the Interior

U.S. Geological Survey 
Cover photograph: Bridge over the Arkansas River near Bentley, Kansas.

Photograph by Mike Holt, U.S. Geological Survey, March 13, 2012. 


\section{Determination of Streamflow of the Arkansas River near Bentley in South- Central Kansas}

By Charles A. Perry

Prepared in cooperation with the City of Wichita, Kansas

Scientific Investigations Report 2012-5059 


\title{
U.S. Department of the Interior \\ KEN SALAZAR, Secretary \\ U.S. Geological Survey \\ Marcia K. McNutt, Director
}

\author{
U.S. Geological Survey, Reston, Virginia: 2012
}

For more information on the USGS - the Federal source for science about the Earth, its natural and living resources, natural hazards, and the environment, visit http://www.usgs.gov or call 1-888-ASK-USGS.

For an overview of USGS information products, including maps, imagery, and publications, visit http://www.usgs.gov/pubprod

Although this report is in the public domain, permission must be secured from the individual copyright owners to reproduce any copyrighted materials contained within this report.

Suggested citation:

Perry, C.A., 2012, Determination of streamflow of the Arkansas River near Bentley in south-central Kansas:

U.S. Geological Survey Scientific Investigations Report 2012-5059, 7 p. 


\section{Contents}

Abstract

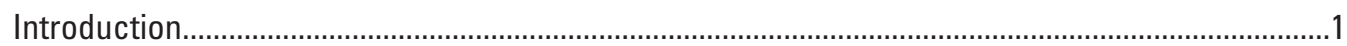

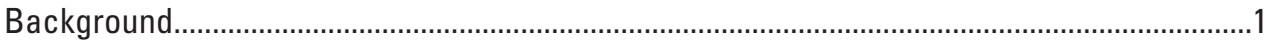

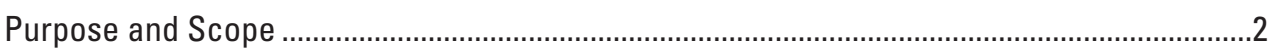

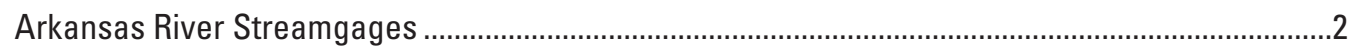

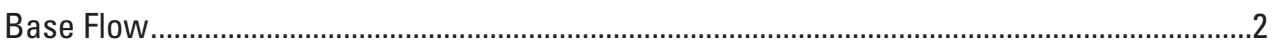

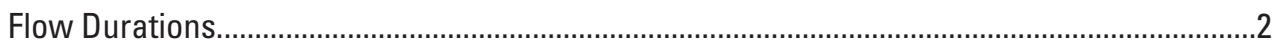

Low Streamflows and Loss of Streamflow to Alluvial Aquifer ....................................................

Concurrent Streamflow at Streamgages near Maize, Bentley, and Hutchinson ................................

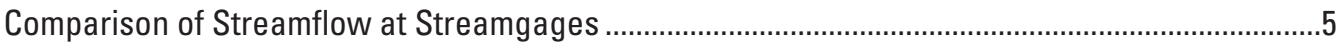

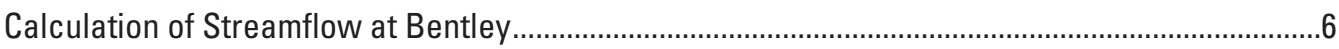

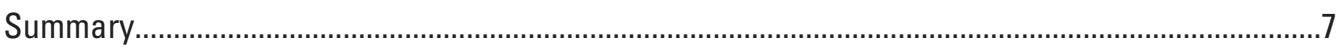

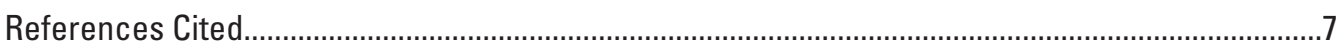

\section{Figures}

1. Map showing study area and location of streamgages on the Arkansas River, and the Bentley well field ...........................................................................................................

2. Graph showing flow-duration curves for the Arkansas River near Hutchinson and near Maize, Kansas, for water years 1988 to 2011

3. Graph showing annual total number of days during which the streamflow for both Hutchinson and Maize was less than 300 cubic feet per second, and total number of days during which the streamflow near Maize minus the streamflow at Hutchinson was less than 0 cubic feet per second, for water years 1987 to 2011 ...............................5

4. Graph showing daily streamflow less than 500 cubic feet per second for the Arkansas River near Hutchinson as a function of the flow of the Arkansas River near Maize during the period October 1, 1987, to September 30, 2011 ..................................................

5. Graph showing measured flows at Arkansas River near Hutchinson as a function of the flow of the Arkansas River near Bentley greater than 5.6 and less than 300 cubic feet per second during the period July 1, 2008, to September 30, 2011.........................6

6. Graph showing measured flows at Arkansas River near Maize as a function of the flow of the Arkansas River near Bentley greater than 5.6 and less than 300 cubic feet per second during the period July 1, 2008, to September 30, 2011. 


\section{Conversion Factors and Abbreviations}

\begin{tabular}{|c|c|c|}
\hline Multiply & By & To obtain \\
\hline \multicolumn{3}{|c|}{ Length } \\
\hline foot $(\mathrm{ft})$ & 0.3048 & meter $(\mathrm{m})$ \\
\hline mile (mi) & 1.609 & kilometer (km) \\
\hline \multicolumn{3}{|c|}{ Area } \\
\hline square mile $\left(\mathrm{mi}^{2}\right)$ & 2.590 & square kilometer $\left(\mathrm{km}^{2}\right)$ \\
\hline \multicolumn{3}{|c|}{ Volume } \\
\hline gallon (gal) & 0.003785 & cubic meter $\left(\mathrm{m}^{3}\right)$ \\
\hline million gallons (Mgal) & 3,785 & cubic meter $\left(\mathrm{m}^{3}\right)$ \\
\hline \multicolumn{3}{|c|}{ Flow rate } \\
\hline cubic foot per second $\left(\mathrm{ft}^{3} / \mathrm{s}\right)$ & 0.02832 & cubic meter per second $\left(\mathrm{m}^{3} / \mathrm{s}\right)$ \\
\hline million gallons per day (Mgal/d) & 0.04381 & cubic meters per second $\left(\mathrm{m}^{3} / \mathrm{s}\right)$ \\
\hline \multicolumn{3}{|c|}{ Hydraulic gradient } \\
\hline foot per mile (ft/mi) & 0.1894 & meter per kilometer $(\mathrm{m} / \mathrm{km})$ \\
\hline
\end{tabular}

Water year is the 12-month period, October 1 through September 30 . The water year is designated by the year in which it ends. Thus, the year ending September 30, 1994, is called the "1994 water year." 


\title{
Determination of Streamflow of the Arkansas River near Bentley in South-Central Kansas
}

\author{
By Charles A. Perry
}

\section{Abstract}

The Kansas Department of Agriculture, Division of Water Resources, requires that the streamflow of the Arkansas River just upstream from Bentley in south-central Kansas be measured or calculated before groundwater can be pumped from the well field. When the daily streamflow of the Arkansas River near Bentley is less than 165 cubic feet per second $\left(\mathrm{ft}^{3} / \mathrm{s}\right)$, pumping must be curtailed. Daily streamflow near Bentley was calculated by determining the relations between streamflow data from two reference streamgages with a concurrent record of 24 years, one located 17.2 miles (mi) upstream and one located $10.9 \mathrm{mi}$ downstream, and streamflow at a temporary gage located just upstream from Bentley (Arkansas River near Bentley, Kansas). Flow-duration curves for the two reference streamgages indicate that during 1988-2011, the mean daily streamflow was less than $165 \mathrm{ft}^{3} / \mathrm{s} 30$ to 35 percent of the time. During extreme lowflow (drought) conditions, the reach of the Arkansas River between Hutchinson and Maize can lose flow to the adjacent alluvial aquifer, with streamflow losses as much as 1.6 cubic feet per second per mile.

Three models were developed to calculate the streamflow of the Arkansas River near Bentley, Kansas. The model chosen depends on the data available and on whether the reach of the Arkansas River between Hutchinson and Maize is gaining or losing groundwater from or to the adjacent alluvial aquifer. The first model was a pair of equations developed from linear regressions of the relation between daily streamflow data from the Bentley streamgage and daily streamflow data from either the Arkansas River near Hutchinson, Kansas, station (station number 07143330) or the Arkansas River near Maize, Kansas, station (station number 07143375). The standard error of the Hutchinson-only equation was $22.8 \mathrm{ft}^{3} / \mathrm{s}$, and the standard error of the Maize-only equation was $22.3 \mathrm{ft}^{3} / \mathrm{s}$. The single-station model would be used if only one streamgage was available. In the second model, the flow gradient between the streamflow near Hutchinson and the streamflow near Maize was used to calculate the streamflow at the Bentley streamgage. This equation resulted in a standard error of $26.7 \mathrm{ft}^{3} / \mathrm{s}$. In the third model, a multiple regression analysis between both the daily streamflow of the Arkansas River near Hutchinson, Kansas, and the daily streamflow of the Arkansas River near Maize, Kansas, was used to calculate the streamflow at the Bentley streamgage. The multiple regression equation had a standard error of $21.2 \mathrm{ft}^{3} / \mathrm{s}$, which was the smallest of the standard errors for all the models.

An analysis of the number of low-flow days and the number of days when the reach between Hutchinson and Maize loses flow to the adjacent alluvial aquifer indicates that the long-term trend is toward fewer days of losing conditions. This trend may indicate a long-term increase in water levels in the alluvial aquifer, which could be caused by one or more of several conditions, including an increase in rainfall, a decrease in pumping, a decrease in temperature, and an increase in streamflow upstream from the Hutchinson-to-Maize reach of the Arkansas River.

\section{Introduction}

\section{Background}

The Kansas Department of Agriculture, Division of Water Resources, requires that the streamflow of the Arkansas River just upstream from Bentley in south-central Kansas be measured or calculated before groundwater can be pumped from the well field. When the daily streamflow of the Arkansas River near Bentley is less than 165 cubic feet per second $\left(\mathrm{ft}^{3} / \mathrm{s}\right)$, pumping from the Bentley well field must be curtailed (Kansas Department of Agriculture, written commun., 2008). The streamflow data must be electronically accessible on a real-time basis. Therefore, in 2008 the U.S. Geological Survey (USGS), in cooperation with the City of Wichita, Kansas, installed a streamgage at the Bentley Road Bridge, located immediately upstream from the well field, to monitor the streamflow of the Arkansas River. The streamgage was equipped with telemetry to provide continuous streamflow data to the Kansas Department of Agriculture, Division of Water Resources. 


\section{Purpose and Scope}

In this report, the data obtained at the Arkansas River near Bentley, Kansas, streamgage during the period July 1, 2008, through September 30, 2011, are used to develop relations between Arkansas River streamflow at the Bentley Road Bridge and at sites upstream and downstream from the bridge. Streamgages on the Arkansas River near Hutchinson (station number 07143330; upstream site) and the Arkansas River near Maize, Kansas (station number 07143375; downstream site), are used in this analysis. The relations developed are applicable to both gaining and losing streamflow conditions in the reach between Hutchinson and Maize. An evaluation is made to determine whether streamflow at the Bentley Road Bridge can be estimated accurately (within 10 percent) using realtime daily data from the upstream and downstream sites; if so, the streamgage at the Bentley Road Bridge could be removed, resulting in an economic savings for the State of Kansas. The trend in the number of days per year of losing streamflow conditions also is evaluated.

\section{Arkansas River Streamgages}

The Arkansas River enters Kansas near Coolidge, Kansas; flows generally eastward through the southern parts of Kansas; and exits the state southeast of Wichita. The alluvium of the river between the Cities of Hutchinson and Wichita consists of clay, silt, and sand and forms the alluvial aquifer. The channel bed consists of mostly sand and some clay, which results in a wide, shallow channel at low streamflow. Because no resistant bedrock is present near the surface, the scour and deposition of sediments during high streamflow causes the elevation of the channel bed to vary. This variability in elevation is responsible for the required shifts in the stagedischarge relation at low flow for streamgages along this reach of the river. Many low-streamflow measurements are needed to establish a good stage-discharge relation. The quality of compiled low-streamflow records for the Arkansas River streamgages is generally rated good (accuracy of 95 percent of daily discharges within 10 percent) except those measured during the winter, which are rated poor (accuracy of 95 percent of daily discharges greater than 15 percent) as a result of ice formation (Rantz, 1982 ).

The upstream gage, Arkansas River near Hutchinson, Kansas (station number 07143330, fig. 1 ), has a 52-year record that extends from October 1, 1959, to the present (2011). The streamgage is located at mile 800.3 from the confluence of the Arkansas and Mississippi Rivers and has a total drainage area of approximately 38,910 square miles $\left(\mathrm{mi}^{2}\right)$, of which $7,186 \mathrm{mi}^{2}$ is noncontributing. This site is 17.2 river miles upstream from the Bentley streamgage (station number 07143350, fig. 1) (U.S. Geological Survey, 2011a).

The downstream gage, Arkansas River near Maize, Kansas (station number 07143375, fig. 1), has been in operation since March 1987 and has more than 24 years of record. It is located at mile 772.2, $10.9 \mathrm{mi}$ downstream from the Bentley streamgage, and has an approximate total drainage area of 39,110 $\mathrm{mi}^{2}$ (U.S. Geological Survey, 2011a).

The streamgage near the Bentley well field, Arkansas River near Bentley, Kansas (station number 07143350, fig. 1), is located at river mile 783.1 and has a total drainage area of $39,050 \mathrm{mi}^{2}$, only $60 \mathrm{mi}^{2}$ less than the area draining to the gage near Maize. The streamflow of the Arkansas River near Bentley, Kansas, has been recorded since July 1, 2008 (U.S. Geological Survey, 2011a).

\section{Base Flow}

Base flow is that streamflow that occurs in the stream without storm runoff. The base flow of the Arkansas River between Hutchinson and Wichita is dependent on the groundwater level in the alluvial aquifer that supplies water to the river. If the top of the saturated zone (water table) of the alluvial aquifer is lower in elevation than the surface of the water in the river, water will move from the river into the aquifer, resulting in a net loss from the river. At this point the river is losing water and streamflow decreases downstream. Groundwater pumpage from the alluvium near the river can lower the water table, especially during drought conditions when storm runoff is limited or nonexistent. During periods of storm runoff, the alluvial aquifer is recharged by soil infiltration and, to a lesser extent, by interflow along the stream-aquifer interface. The additional drainage area from the gage at Bentley to the gage near Maize is approximately $60 \mathrm{mi}^{2}$. This difference is important during high streamflow, when instantaneous peak streamflow increases by approximately the square root of the drainage area (Izzard, 1954). For low streamflow, the volume of water stored in the alluvial aquifer, the transmissivity of the aquifer, and the elevation of the water table are most critical to maintaining base flow (Freeze and Cherry, 1979).

\section{Flow Durations}

Flow duration is the cumulative distribution of daily streamflow at a particular site. Values that indicate the percentage of time that the daily flow is equaled or exceeded define the curve. The flow durations for the Arkansas River gages near Hutchinson and near Maize, Kansas, are from the same period of record: October 1, 1987, to September 30, 2011 (fig. 2). Streamflow data for the period 1987-2011 were obtained from the USGS National Water Information System data base (U.S. Geological Survey, 2011a). Daily streamflow at the gage near Hutchinson exceeded $165 \mathrm{ft}^{3} / \mathrm{s} 70$ percent of the time. Daily streamflow at the gage near Maize exceeded $165 \mathrm{ft}^{3} / \mathrm{s} 65$ percent of the time. Therefore, streamflow at the gages near Hutchinson and Maize is near (plus or minus about $10 \mathrm{ft}^{3} / \mathrm{s}$ ) or less than the $165 \mathrm{ft}^{3} / \mathrm{s}$ needed to maintain pumping at the Bentley well field about one-third of the time. Because the flow durations are higher at the gage near Maize than at the 


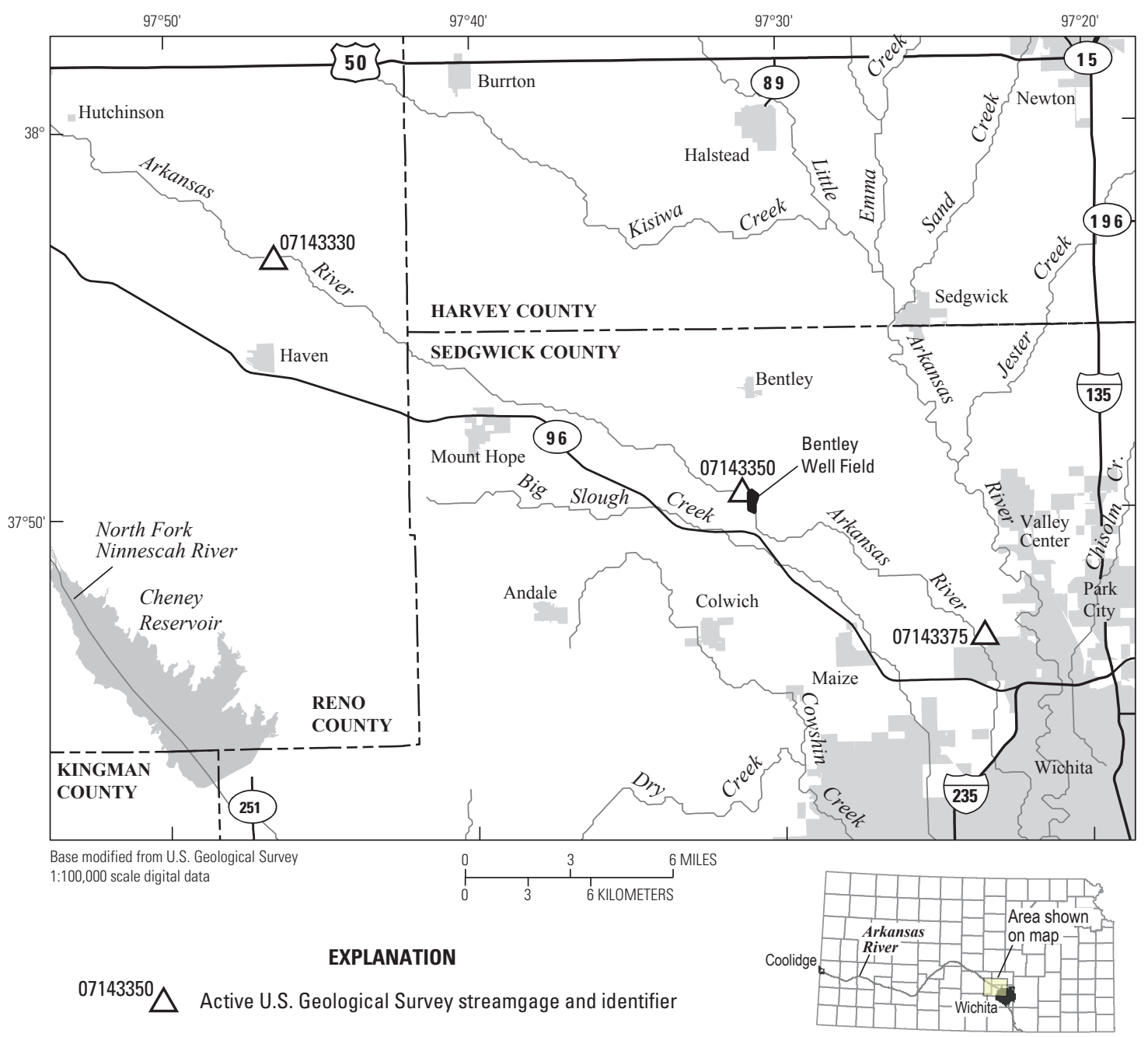

Figure 1. Location of streamgages on the Arkansas River and the Bentley Well Field.

gage near Hutchinson, the stream reach that includes the Bentley well field streamgage is a gaining reach. The two flowduration curves are similar at flows above $200 \mathrm{ft}^{3} / \mathrm{s}$; below $200 \mathrm{ft}^{3} / \mathrm{s}$, however, streamflow can be greater near Hutchinson than near Maize as a result of drought conditions. In fact, the 95-percent exceedance value for the Maize gage $\left(52 \mathrm{ft}^{3} / \mathrm{s}\right)$ is less than the 95-percent exceedance value for the Hutchinson gage $\left(73 \mathrm{ft}^{3} / \mathrm{s}\right)$, further indicating that the stream reach from Hutchinson to Maize reach loses water to the alluvial aquifer during extreme low flows.

\section{Low Streamflows and Loss of Streamflow to Alluvial Aquifer}

The lowest recorded instantaneous streamflow at the Hutchinson gage was $27 \mathrm{ft}^{3} / \mathrm{s}$ on September 13, 1980 (U.S. Geological Survey, 2011b). At the Maize gage, the lowest instantaneous streamflow was $0.80 \mathrm{ft}^{3} / \mathrm{s}$ on September 15, 2011, after an extended summer drought (Howard, 2011). On that day, the Hutchinson gage recorded a mean daily streamflow of $42 \mathrm{ft}^{3} / \mathrm{s}$, the Bentley gage recorded $8 \mathrm{ft}^{3} / \mathrm{s}$, and the Maize gage recorded $0.97 \mathrm{ft}^{3} / \mathrm{s}$. On that day, and probably other days with extreme low streamflows, the Arkansas River between Hutchinson and Maize became a losing reach as a result of evaporation, flow into the alluvial aquifer, and surface-water withdrawals, depleting the surface-water flow in the Hutchinson-to-Maize reach as much as 98 percent.

When the water table in the alluvial aquifer near the river is lower than the water level in the stream, water flows from the river channel into the alluvial aquifer. If this occurs within the Hutchinson-to-Maize reach, the streamflow at the gage near Hutchinson is greater than the streamflow downstream near Maize. The streamflow records for the gages near Hutchinson and near Maize from October 1, 1987, to September 30, 2011, were analyzed for periods of streamflow loss. For this analysis, an arbitrary value of $300 \mathrm{ft}^{3} / \mathrm{s}$ was selected, which is approximately equal to the median flow for each gage and represents an upper limit for the base flow of the river. The daily mean streamflow at the Maize gage was subtracted from the daily mean streamflow at the Hutchinson gage. Negative results indicated that the river was losing water along that reach. The annual total number of days when streamflow was 


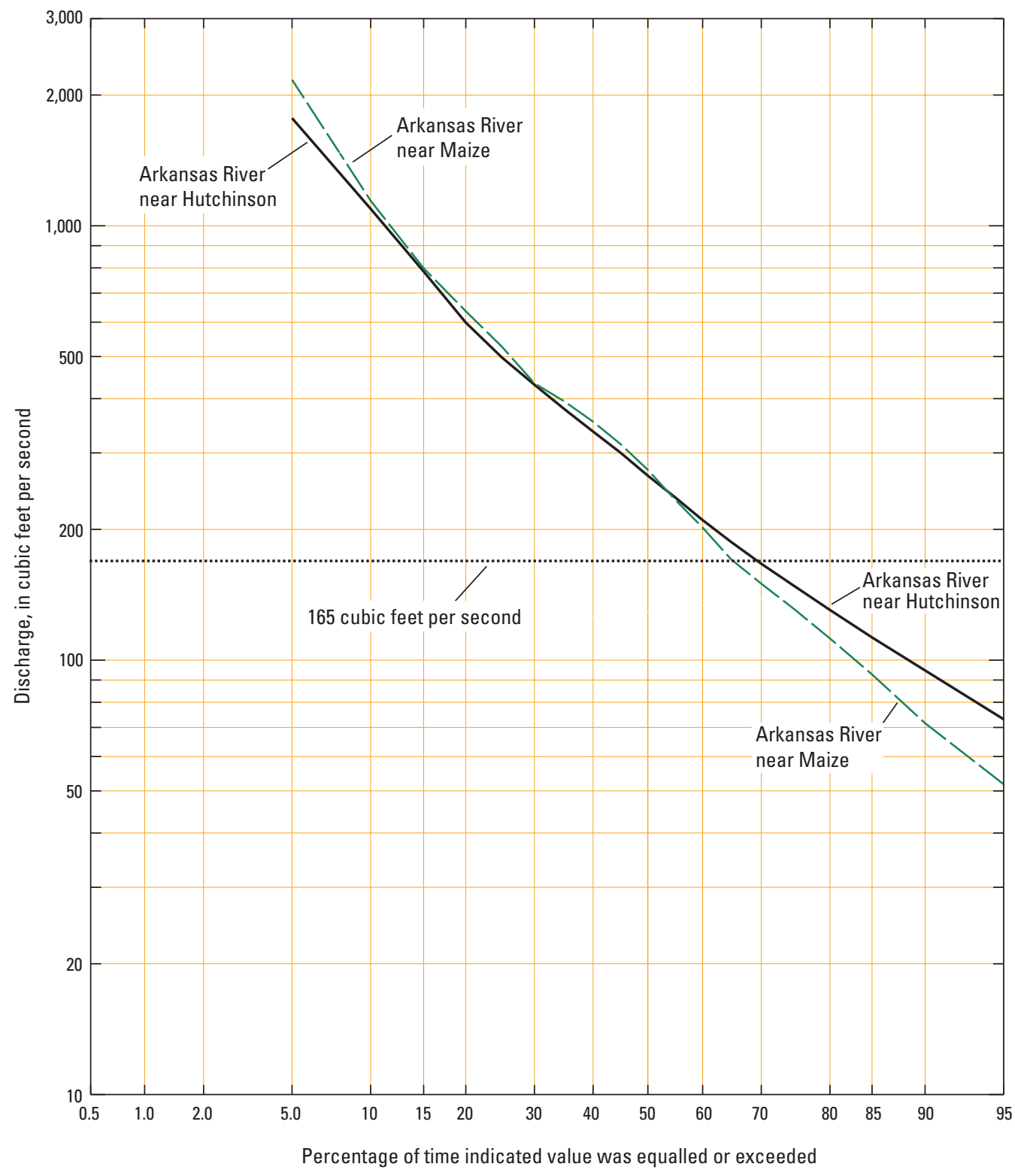

Figure 2. Flow duration curves for the Arkansas River near Hutchinson and near Maize, Kansas, for water years 1988 to 2011.

less than $300 \mathrm{ft}^{3} / \mathrm{s}$ at either streamgage and the annual number of days of negative flow difference between the Maize and Hutchinson gages are shown in figure 3. The Mann-Kendall trend line (Helsel and Hirsch, 1992) for the relation between these two values, which indicates the number of days with negative differences, shows that the trend of fewer days with negative differences from 1988 to 2011 is significant (slope $=-2.5$ days per year) at a 95 -percent confidence level. This result may indicate a long-term increase in water levels in the alluvial aquifer, or could be caused by several conditions, including an increase in rainfall, a decrease in pumpage from the alluvial aquifer, a decrease in temperature, and (or) an increase in streamflow upstream from the Hutchinsonto-Maize reach of the Arkansas River during the period 1988-2011.

\section{Concurrent Streamflow at Streamgages near Maize, Bentley, and Hutchinson}

At the time of this analysis, (November 2011), the available streamflow record for the Bentley streamgage was 40 months long. The minimum daily streamflow during this period was $5.6 \mathrm{ft}^{3} / \mathrm{s}$ on September 14, 2011 (U.S. Geological Survey, 2011b). The stage-discharge relation (rating curve) for the Arkansas River near Bentley, Kansas, has been extended down to $2.0 \mathrm{ft}^{3} / \mathrm{s}$. Currently (November 2011), when the river stage for the Arkansas River near Bentley, Kansas, falls below 12.44 feet above the gage datum, the flow is less than $165 \mathrm{ft}^{3} / \mathrm{s}$. 


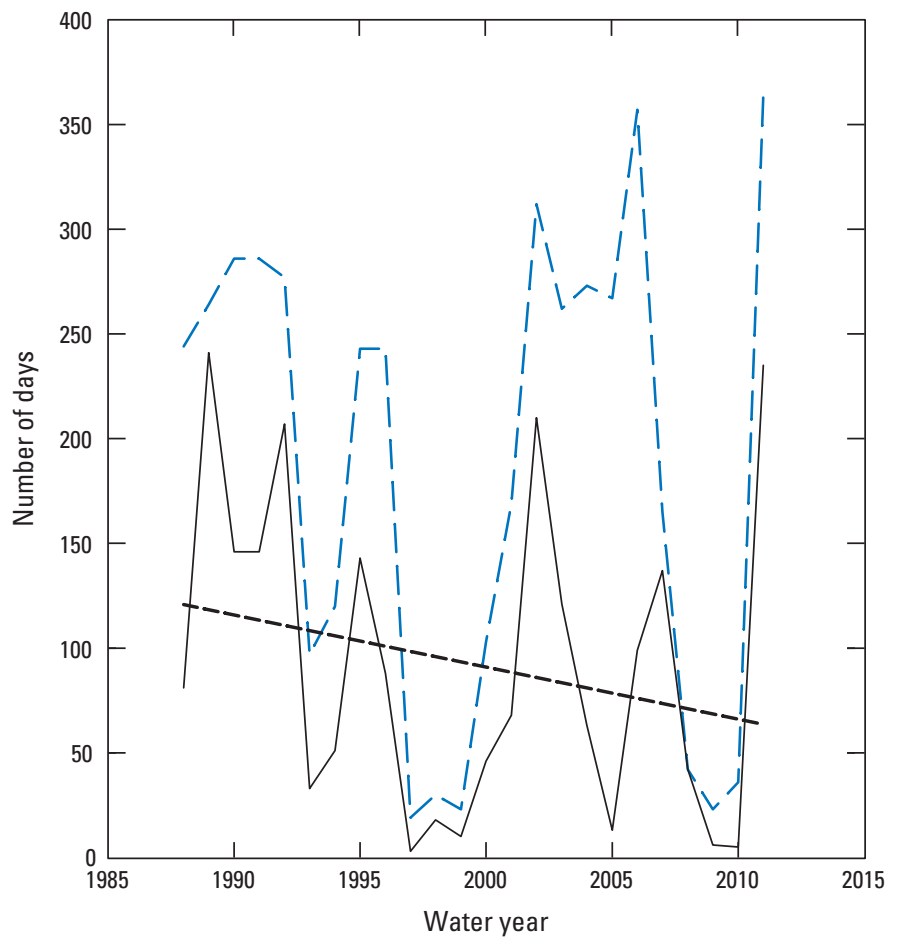

EXPLANATION

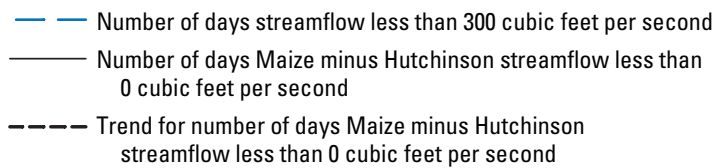

Figure 3. Annual (water year) total number of days where the streamflow for both Hutchinson and Maize was less than 300 cubic feet per second, and the total number of days where the streamflow near Maize minus the streamflow at Hutchinson was less than 0 cubic feet per second for the period 1987 to 2011.

Daily streamflow at the Bentley gage was less than $165 \mathrm{ft}^{3} / \mathrm{s}$ on 158 days during the 40 -month study period (July 1,2008 , to September 30,2011), which was only slightly more than 13 percent of the time. The flow-duration curves (fig. 2) indicate that streamflow should be less than $165 \mathrm{ft}^{3} / \mathrm{s} 30$ to 35 percent of the time. Therefore, daily flow of the Arkansas River along the Hutchinson-to-Maize reach was greater than expected during the study period.

\section{Comparison of Streamflow at Streamgages}

Before the installation of the gage near Bentley, streamflow data were examined for additional low-flow values. Daily streamflow data for the Arkansas River near Hutchinson were compared to the daily streamflow for the Arkansas River near Maize from 1987 to 2011 in figure 4. The points that plot below the 1:1 line are those days when the streamflow near Hutchinson was greater than the streamflow near Maize. Most of the time the streamflow increased downstream (points plot above the 1:1 line).

To determine when the streamflow of the Arkansas River near Bentley reaches $165 \mathrm{ft}^{3} / \mathrm{s}$, two cases must be examined. The first case is when the reach of the Arkansas River between Hutchinson and Maize is a gaining reach. In this case, the streamflow near Hutchinson could be less than $165 \mathrm{ft}^{3} / \mathrm{s}$ and the streamflow near Maize could be greater than $165 \mathrm{ft}^{3} / \mathrm{s}$. The second case is when that reach is a losing reach. In this case, the streamflow near Maize could be less than $165 \mathrm{ft}^{3} / \mathrm{s}$ and the streamflow near Hutchinson could be greater than $165 \mathrm{ft}^{3} / \mathrm{s}$.

Care should be taken when the difference between the streamflow near Hutchinson and the streamflow near Maize is very large (greater than $100 \mathrm{ft}^{3} / \mathrm{s}$ ). Small runoff events near either gage could lead to the false assumption that water is moving from the stream into the alluvial aquifer when instead a small flood wave is moving downstream. Given the lowflow criterion (less than $300 \mathrm{ft}^{3} / \mathrm{s}$ ) established for the models developed in this study, daily streamflows computed for station 07143350 (near Bentley) are valid when daily streamflow at station 07143330 (near Hutchinson) is less than $300 \mathrm{ft}^{3} / \mathrm{s}$. When the flow is equal or greater than $300 \mathrm{ft}^{3} / \mathrm{s}$, computations of streamflow from the models can still be made, but they are beyond the scope of this report.

The maximum loss along the Arkansas River between Hutchinson and Maize (when streamflow near Maize was less than $165 \mathrm{ft}^{3} / \mathrm{s}$ ) occurred on September 2, 2011, when an

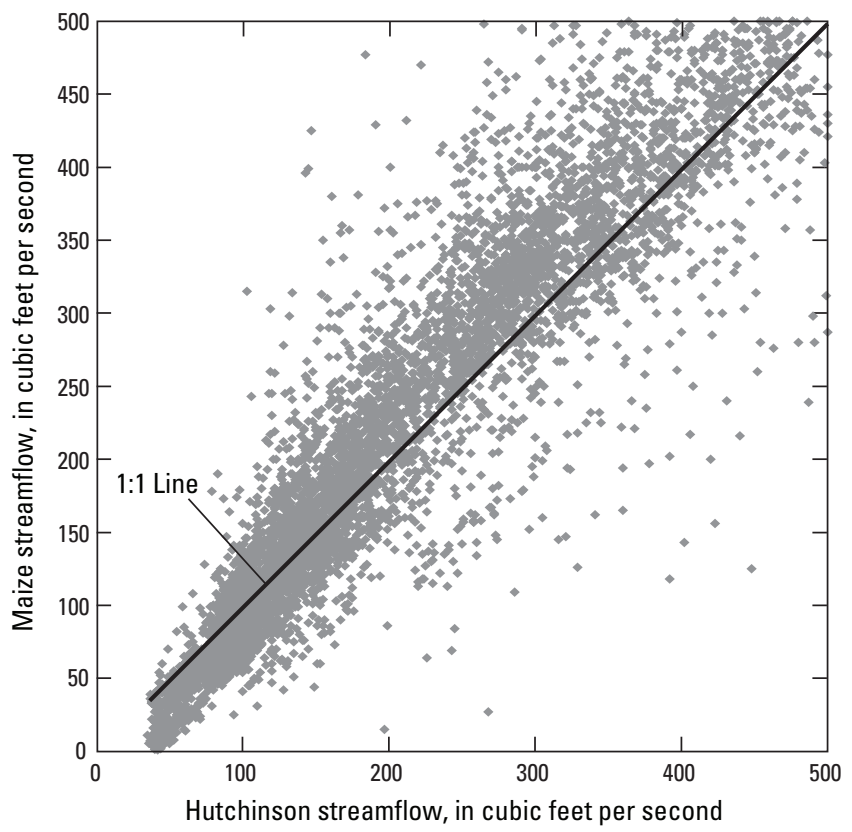

Figure 4. Daily streamflow less than 500 cubic feet per second for the flow of the Arkansas River near Hutchinson versus the flow of the Arkansas River near Maize during the period October 1, 1987, to September 30, 2011. Straight line is the 1:1 ratio between respective streamflows. 
average 1.6 cubic feet per second per mile was lost over the 28.1-mi reach. The streamflow near Hutchinson was $53 \mathrm{ft}^{3} / \mathrm{s}$ and that near Maize was $7.7 \mathrm{ft}^{3} / \mathrm{s}$. By using the same loss per mile, the streamflow near Bentley could have been $25.5 \mathrm{ft}^{3} / \mathrm{s}$.

\section{Calculation of Streamflow at Bentley}

For the first model used to estimate streamflow of the Arkansas River near Bentley, measured streamflow of the Arkansas River near Bentley, Kansas, between the values of 5.6 and $300 \mathrm{ft}^{3} / \mathrm{s}$ was compared with streamflow of the Arkansas River near Hutchinson (fig. 5) and with streamflow of the Arkansas River near Maize (fig. 6). The value of $300 \mathrm{ft}^{3} / \mathrm{s}$ is approximately the median flow value for the reach of the Arkansas River between Hutchinson and Maize and represents an upper limit to the base flow of the river. A linear regression (Helsel and Hirsch , 1992) between each of the two data sets in each graph (figs. 5 and 6) explains 93.1 and 93.4 percent, respectively, of the variability of streamflow between the Bentley streamgage and the Hutchinson and Maize streamgages. The standard error of estimate was similar for each equation, with a value of $22.8 \mathrm{ft}^{3} / \mathrm{s}$ when only streamflow at Hutchinson is used and a value of $22.3 \mathrm{ft}^{3} / \mathrm{s}$ when only streamflow at Maize is used. The average percent error was 19.1 for Hutchinson and 20.4 for Maize . Equations for the single-station model would be used if only one streamgage was available. These equations are:

Bentley streamflow $=1.062$ (Hutchinson streamflow) -16.92 Bentley streamflow $=0.773$ (Maize streamflow) +28.77 .

A second model used to estimate the streamflow of the Arkansas River near Bentley consists of determining the flow gradient between the streamgage near Hutchinson and

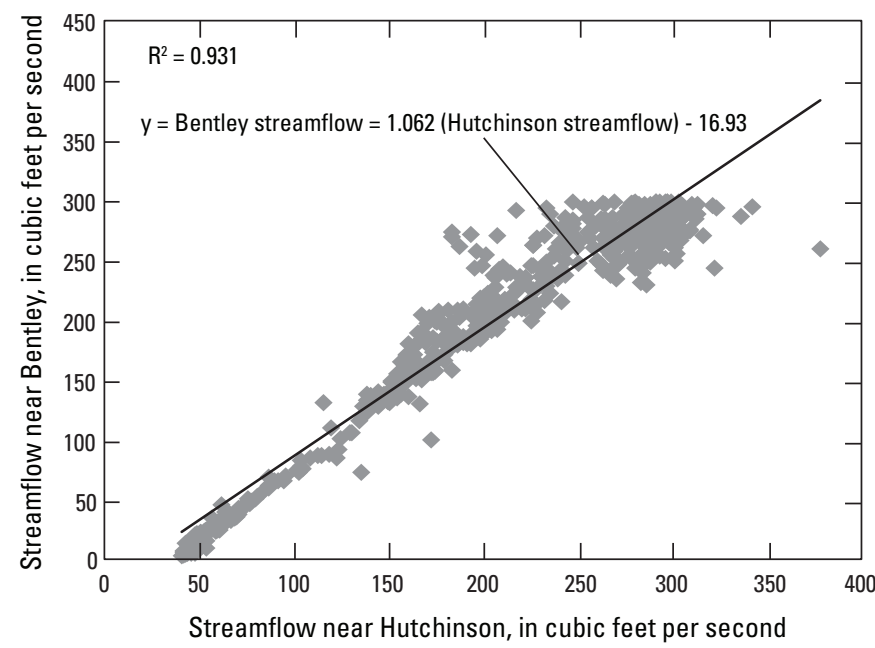

Figure 5. Comparison of measured flows at Arkansas River near Hutchinson with the flow of the Arkansas River near Bentley greater than 5.6 and less than 300 cubic feet per second during the period July 1, 2008 to September 30, 2011.

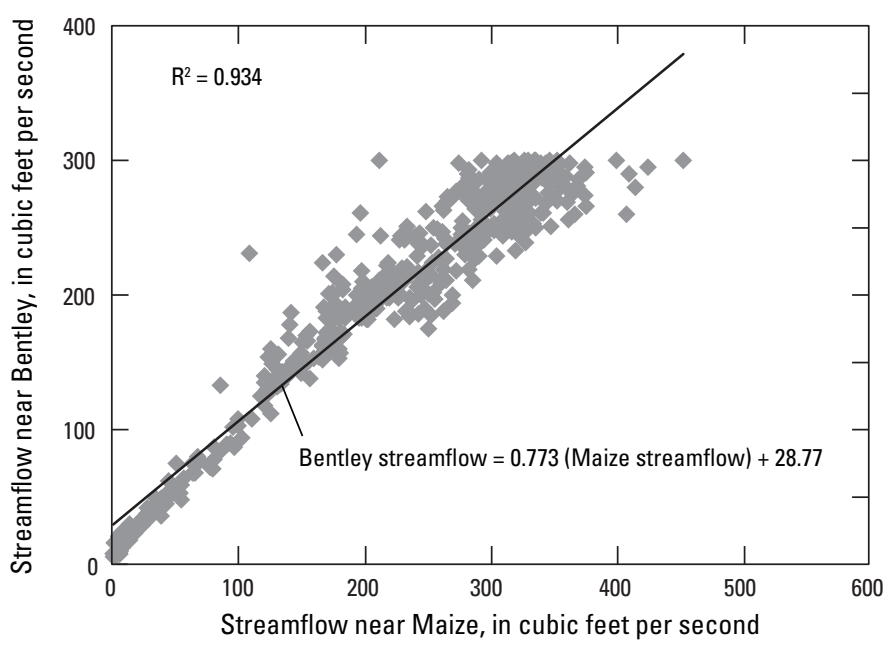

Figure 6. Comparison of measured flows at Arkansas River near Maize with the flow of the Arkansas River near Bentley greater than 5.6 and less than 300 cubic feet per second during the period July 1, 2008 to September 30, 2011.

the streamgage near Maize. The gradient is multiplied by the distance from the Hutchinson gage downstream to the Bentley gage to estimate the streamflow near Bentley. These modeled values are compared with the observed streamflow at Bentley with 95.5 percent of the variability explained. The standard error of estimate for the gradient model is $26.7 \mathrm{ft}^{3} / \mathrm{s}$. The average percent difference between modeled and observed streamflow for the data set is 13.6 percent. The flow-gradient model can be used in all low-flow conditions, whether the river is gaining or losing streamflow. This equation could be used when the estimated flow is below $300 \mathrm{ft}^{3} / \mathrm{s}$. The equation is:

Bentley streamflow $=(($ Maize streamflow $)-($ Hutchinson streamflow) $/ 28.1) * 17.2)+($ Hutchinson streamflow $)$

A third model is a multiple regression (Helsel and Hirsch, 1992) using streamflow data from the Arkansas River near Hutchinson and near Maize. A relation was developed for streamflow between 5.6 and $300 \mathrm{ft}^{3} / \mathrm{s}$ at the Bentley gage. This relation explains 96.7 percent of the variability. The standard error of estimate for the multiple regression equation is $21.2 \mathrm{ft}^{3} / \mathrm{s}$. The average percent difference between modeled and observed streamflow for the data set is 10.2 percent. The multiple regression equation is:

Bentley streamflow $=0.415$ (Maize streamflow) +0.632

(Hutchinson streamflow) -13.0 .

Valid estimates of streamflow at the Bentley streamgage from the various models are restricted to values greater than $5.6 \mathrm{ft}^{3} / \mathrm{s}$. The single-station models would be used if only one of the two streamgages was functioning. The multiple regression model would be the most appropriate to use as it has the lowest standard error $\left(21.2 \mathrm{ft}^{3} / \mathrm{s}\right)$. Even though the standard error of the gradient model $\left(26.7 \mathrm{ft}^{3} / \mathrm{s}\right)$ is greater than that of 
the regression model $\left(21.2 \mathrm{ft}^{3} / \mathrm{s}\right)$, the gradient model would provide an alternate estimate during periods when the river was losing streamflow and when the estimated flow at the Bentley Bridge was less than $165 \mathrm{ft}^{3} / \mathrm{s}$.

\section{Summary}

The Kansas Department of Agriculture, Division of Water Resources, requires that the streamflow of the Arkansas River just upstream from the Bentley well field in south-central Kansas be measured or calculated before groundwater can be pumped from the well field. When the daily streamflow of the Arkansas River near Bentley is less than 165 cubic feet per second $\left(\mathrm{ft}^{3} / \mathrm{s}\right)$, pumping must be curtailed. Daily streamflow near Bentley was calculated by determining the relations between streamflow data from two reference streamgages with a concurrent record of 24 years, one located 17.2 miles (mi) upstream and one located $10.9 \mathrm{mi}$ downstream, and streamflow at a temporary gage located just upstream from Bentley (Arkansas River near Bentley, Kansas).

Three models were developed to calculate the streamflow of the Arkansas River near Bentley, Kansas. All of the models explained more than 90 percent of the variability of the streamflow near Bentley. The first model was a pair of equations developed from linear regressions of the relation between streamflow data at the Bentley streamgage and streamflow data from the Arkansas River near Hutchinson, Kansas station number 07143330) and the Arkansas River near Maize, Kansas (station number 07143375). The Hutchinsononly equation had an average percent error of 19.1 percent and a standard error of $22.8 \mathrm{ft}^{3} / \mathrm{s}$, and the Maize-only equation had an average percent error of 20.4 percent and a standard error of $22.3 \mathrm{ft}^{3} / \mathrm{s}$. This single-station model would be used if only one streamgage was available. The second model used the flow gradient between the streamflow near Hutchinson and the streamflow near Maize. The flow-gradient model had an average percent error of 13.6 percent and a standard error of $26.7 \mathrm{ft}^{3} / \mathrm{s}$. The flow gradient model explains 95.5 percent of the streamflow variability and is most appropriate for use in all low-flow conditions, especially when the estimated flow at Bentley is less than $165 \mathrm{ft}^{3} / \mathrm{s}$.

The third model used a multiple regression analysis between streamflow at the Arkansas River near Hutchinson, Kansas, and streamflow at the Arkansas River near Maize, Kansas. The multiple regression analysis using both stations resulted in an equation with a standard error of $21.2 \mathrm{ft}^{3} / \mathrm{s}$ and an average error of 10.2 percent that explains 96.7 percent of the variability of the flow at the Bentley gage. Therefore, the multiple regression equation is the model of choice for determining the flow at the Bentley gage. A conservative estimate of the flow of the Arkansas River at Bentley would be an average of the values determined from the gradient and regression models.
An analysis of the number of days in each year during 1988-2011 when the flow was less than $300 \mathrm{ft}^{3} / \mathrm{s}$ and the number of days when the Hutchinson-to-Maize reach was losing water revealed a trend in which the number of negative flow days decreased with time. This trend may be indicative of a long-term increase in water levels in the alluvial aquifer. A long-term increase in water levels could be caused by any or a combination of several conditions, including an increase in rainfall, a decrease in pumpage, a decrease in temperature, and an increase in streamflow upstream from the Hutchinson-toMaize reach of the Arkansas River.

\section{References Cited}

Feeeze, R. Allan, and Cherry, John A., 1979, Groundwater: Englewood Cliffs, N.J., Prentice-Hall, Inc, 604 p.

Helsel, D.R., and Hirsch, R.M., 1992, Statistical methods in water resources: Techniques of Water-Resources Investigations Report, Book 4, Chapter A3, U.S. Geological Survey, $522 \mathrm{p}$.

Izzard, C.F., 1954, Peak discharge for highway drainage design: Transactions of the American Society of Civil Engineering, CXIX, p. 1,005-1,015.

Rantz, S, 1982, Measurement and computation of streamflow; Volume 1, Measurement of state and discharge; Volume 2, Computation of discharge: U.S. Geological Survey WaterSupply Paper 2175, 631 p.

Howard, Fran, 2011, Kansas drought takes toll on wheat and early alfalfa: AGWEB, accessed February 15, 2012, at http://www.agweb.com/article/kansas_drought_takes_toll_ on_wheat_and_early_alfalfal.

U.S. Geological Survey, 2011a, National Water Information System (NWIS): U.S. Geological Survey database accessed November 30, 2011, at http://waterdata.usgs.gov/NWIS/.

U.S. Geological Survey, 2011b, Water-resources data for the United States, water year 2011: U.S. Geological Survey Water-Resources Data Report WDR-US-2011, site 07143350, accessed November 30, 2011, at http://wdr.water. usgs.gov/wy2011/pdfs/07143350.2011.pdf. 
Publishing support provided by:

Rolla Publishing Service Center

For additional information concerning this publication, contact:

Director, USGS Kansas Water Science Center

4821 Quail Crest Place, Lawrence, KS (785) 842-9909

Or visit the Kansas Water Science Center Web Site at:

http://ks.water.usgs.gov 

